\title{
A formação dos repertórios culturais e a atuação da transferência ${ }^{1}$
}

\author{
Itamar Even-Zohar \\ Tradução por Juliana Steil ${ }^{* *}$
}

\begin{abstract}
RESUMO:
Neste artigo, sugiro uma série de hipóteses para a abordagem das relações entre a formação do repertório e a transferência. É no contexto específico do estudo da tradução em seu sentido aceito que desejo salientar a conjuntura sociocultural onde a transferência atua. A atuação da transferência pode ultrapassar bastante o conjunto dos fatos com os quais os estudantes de tradução normalmente se preocupam, sendo que às vezes ela se torna um fator crucial no destino das sociedades e culturas. Mesmo quando a sua atuação é menor, contudo, a transferência continua presente e se mantém um parâmetro importante no âmbito de uma teoria da tradução mais abrangente.
\end{abstract}

Palavras-chave: repertório cultural; invenção; importação; tradução; transferência.

$O$ repertório cultural. O principal conceito da teoria da cultura que utilizo é o de "repertório". O repertório cultural é o conjunto, ou o estoque aceito, de opções utilizadas por um grupo, e por seus membros individuais, para a organização da vida. $\mathrm{O}$ tamanho do grupo pode variar. Do ponto de vista da pesquisa cultural, como estes grupos sempre dependem de repertórios culturais específicos para a organização de sua vida, eles são por definição entidades culturais.

Os dois aspectos da organização da vida. "Organização" agrupa ao menos dois aspectos diferentes, embora talvez complementares. Nesse sentido, pode-se falar em um aspecto passivo e um aspecto ativo da organização da vida e, consequentemente, em repertórios "passivos" e "ativos".

$O$ aspecto passivo. $\mathrm{O}$ aspecto passivo da organização da vida - que poderia ser melhor identificado como "organizacidade" - é aquele em que o "mundo", por assim dizer, adquire, do ponto de vista de um indivíduo ou de um grupo, uma forma organizada. Esta forma adquirida transmite "significado", torna "o mundo" compreensível em vez de caótico. Esta visão tem firmes raízes em várias teorias da cultura, em especial na semiótica da cultura, assim como em certas tendências do que se vem chamando de "estudos culturais" procedentes principalmente da crítica literária tradicional. Esta perspectiva, na verdade, encontra bases na tradição hermenêutica e exegética: ela vê "o mundo" como um conjunto de signos que, como diz Lotman (1978), nos bombardeia diariamente, precisando, assim, ser interpretado para que a vida se torne possível. A ideia de um sistema modelador, como desenvolvida por Ivanov e Lotman, entre outros semioticistas soviéticos, é antes de tudo a de um conjunto de procedimentos com a ajuda do qual "o mundo faz sentido". A explanação de Lotman e Uspenskij (1971, pp. 146-147; Lotman, 1978) talvez seja melhor: “A principal 'obra' da cultura (...) é a organização estrutural do mundo em redor. A cultura é um gerador de 'estruturização'; ela cria uma esfera social em volta do homem que, como a biosfera, viabiliza a vida (a vida social, no caso, e não a orgânica)" [A partir da tradução de Segal, 1974, pp. 94-95].

$O$ aspecto ativo. $\mathrm{O}$ aspecto ativo da organização pode ser definido como um conjunto de procedimentos que um indivíduo pode realizar para lidar com qualquer situação que ele enfrenta, assim como produzir qualquer situação. Como afirma Swidler, a cultura é "um repertório ou 'kit de ferramentas' de hábitos, habilidades e estilos a partir do qual as pessoas constroem "estratégias de ação"' (Swidler, 1986, p. 273). Esta perspectiva, assim, está ligada sobretudo a ideias de "atuação" e de "atividade" e não às ideias de "compreensão". Também é indispensável certa "compreensão" para a "ação", 
evidentemente, mas o fundamental nesse caso não é "entender" as situações, mas tomar decisões ativas e realizar.

A formação dos repertórios. Os repertórios culturais, embora percebidos pelos membros do grupo como automáticos e, geralmente, como se fossem naturais, não são nem gerados nem herdados por nossos genes, mas precisam ser criados, aprendidos e adotados pelas pessoas, isto é, pelos membros do grupo. Esta formação é permanente e contínua, embora variável em termos de intensidade e volume. Ela pode acontecer inadvertidamente, ou "espontaneamente", isto é, a partir da contribuição de anônimos, cujos nomes e destinos podem nunca ser conhecidos, ou deliberadamente, isto é, a partir da ação de membros conhecidos, e por vezes lembrados, que estão aberta e diligentemente empenhados nesta atividade.

A aceitação do repertório. Independentemente da fonte do repertório, o fator crucial será a aceitação dele ou não, pelo grupo alvo, como ferramenta para a organização da vida. Isso depende de uma intrincada rede de relações, que pode ser identificada concisamente como "sistema da cultura", que inclui fatores como mercado, detentores de poder e os possíveis usuários que servem como interface dinâmica entre essas relações. Claramente, de uma enorme quantidade de itens potenciais para um repertório em qualquer nível, apenas um pequeno número eventualmente se estabelece e se torna instrumental.

Os procedimentos da formação do repertório: invenção e importação. Na formação dos repertórios, independentemente das circunstâncias, os principais procedimentos parecem ser a "invenção" e a "importação". Estes não são procedimentos opostos, já que a invenção pode ser feita via importação, embora possa também referir-se ao trabalho de formação que opera no interior do sistema doméstico sem qualquer ligação com outro sistema. Mesmo nos casos de inventividade que não têm uma fonte simples, a importação pode ter ocorrido. Em suma, a importação tem um papel muito mais crucial na formação dos repertórios do que se costuma admitir, e, consequentemente, na organização da vida dos grupos, assim como na interação entre os grupos.

Da "importação" à "transferência". Existe um fluxo permanente e silencioso, por assim dizer, de importação em todos os momentos da história dos grupos. Tal fluxo pode às vezes reduzir-se a quase nada, mas outras vezes pode ser vigoroso e abundante. Quando os bens - materiais ou semióticos - são importados, se eles prosperam no mercado alvo, eles podem gradativamente tornar-se parte integral do repertório alvo. Isto ocorre quando se observa que eles se tornam óbvios e autoevidentes para o grupo alvo, de fato indispensáveis para a vida. Esta indispensabilidade é manifesta não necessariamente em algum posicionamento explícito, mas na incorporação dos bens ou nas repercussões de sua ausência. A esse estado de importação incorporada em um repertório eu gostaria de chamar "transferência".

Naturalmente, nem todos os bens importados resultam em tais "transferências". De outro lado, nem todas as transferências que efetivamente ocorrem desempenham um papel importante no repertório alvo. O volume e a eficácia da transferência normalmente variam de um período a outro na história dos grupos, assim como nos vários campos de atividades mantidas pelo grupo. Por exemplo, as transferências podem ser fortes no campo da construção, mas podem ao mesmo tempo ser inexistentes no campo da língua. Também há momentos em que tais transferências constituem o procedimento central e mais importante na criação de opções para a organização do grupo e da vida individual, estando intimamente ligadas à própria sobrevivência do grupo.

Quando uma transferência é bem-sucedida, não são apenas os bens em si que se tornam domesticados, mas antes a necessidade desses bens. Obviamente, por exemplo, para que a pimenta-do-reino se torne um ingrediente indispensável numa dieta, é 
necessária ou deve ser criada, com apoio e fomento, a necessidade de fazer comida apimentada de uma maneira específica. De modo semelhante, aqueles que importam textos de uma cultura para a outra (via tradução, por exemplo) podem realizar um ato bemsucedido de transferência quando conseguem fazer com que os modelos semióticos desses textos se tornem partes integrais dos repertórios alvo em vários níveis de atividades socioculturais (desde a escrita de textos ao gerenciamento de situações na vida).

As causas da importação e a trajetória da transferência. O caso mais evidente de importação parece ser aquele em que os bens são trazidos para cumprirem certas funções que estão ausentes no sistema alvo. Isso é, a importação pode ocorrer sempre que os bens importados não estão disponíveis no mercado alvo e uma vontade de consumi-los é de alguma forma despertada nos membros do grupo alvo. Isto se aplica tanto aos chamados bens "materiais" quanto aos bens "semióticos". Por exemplo, importar pimenta-do-reino, certos tecidos ou alimentos pode ser tão complicado, do ponto de vista da comercialização, quanto importar hábitos de higiene, leis explícitas, narrativas e similares.

Naturalmente, o conceito chave aqui é a hipótese da "vontade de consumir novos bens", algo que não é simples de identificar na complexa situação das sociedades. Contudo, mesmo que a situação normal das sociedades possa ser considerada a de oposição à importação e, portanto, à transferência, há claramente circunstâncias em que esta resistência diminui. Nesse sentido, a resistência pode diminuir quando novas situações são introduzidas (as quais podem ser elas próprias casos de importação) e há pouco ou nenhum repertório doméstico para lidar com elas. Por exemplo, uma sociedade sem exército que aceita a função de um exército poderá querer adotar uma grande parcela de repertórios, que pode não ter conexão com qualquer repertório atual ou passado, para manter este exército. Isto ocorre porque a única maneira prática de fazer isso é adotar modelos de organizações militares existentes e acessíveis.

A resistência à transferência também pode diminuir quando alguns ingredientes do repertório (ou um repertório inteiro) se torna indesejado. Quando isto acontece, pode não haver tempo para reposição gradual e, assim, são encontradas e transferidas alternativas existentes. São muitos os exemplos disso, desde casos abrangentes, como a introdução de uma nova religião ou um código de leis (por exemplo, a Islândia medieval, a Turquia moderna), a casos menos abrangentes, como a adoção do modelo literário do soneto, ou o princípio poético da rima.

As transferências podem prosperar, entretanto, não devido a alguma disposição emergente ou existente, mas simplesmente por meio da ocorrência de contatos com outra cultura. Tais contatos podem provocar um sentimento de insuficiência, em especial se o outro repertório é mais rico, tem mais prestígio em meio a muitos grupos, ou até mesmo se ele promete "uma vida melhor". Nesses casos, entra em ação o simples princípio "por que não temos o que nosso vizinho já tem?". Esse princípio, claro, pode ser apenas uma justificativa e uma racionalização e não uma verdadeira causa de transferência, mas, de outro lado, há muitos casos de comércio genuíno de itens cuja necessidade não pode ter surgido de outra forma.

\section{Graus de atuação da transferência}

No nível do repertório passivo, ou seja, as ferramentas de filtro que servem para ver o mundo, a transferência pode plantar imagens do mundo que serão ao menos compatíveis, ou toleradas, pela cultura existente. Mas isso pode ir muito mais longe. Por exemplo, se não houver competição na cena internacional entre vários repertórios de telefilmes, duas ou três indústrias, localizadas em dois ou três países, podem gradativamente fazer com que seus modelos, suas imagens do mundo, sejam internacionalmente aceitos. Estes modelos 
podem tornar-se fatores cruciais para a organização da vida do(s) grupo(s) envolvidos, pois, quer se realizem como filmes ou textos escritos, remetem a questões fundamentais da vida humana, como a interação humana, a vida e a morte, o bem e o mal, o amor e o ódio.

No nível do "repertório ativo", isto é, as ferramentas disponíveis para a ação na vida, o repertório transferido pode ter consequências diretas no modo com que as pessoas começam a agir em seu ambiente imediato. Os "bens" transferidos serão, assim, um novo conjunto de instruções ocultas não para o modo de perceber o mundo, mas para o modo de agir nele.

O trabalho dos agentes como itens de repertório transferido. O conceito de "bens" (e de "produtos") também abrangem, a meu ver, as imagens projetadas para a sociedade por pessoas empenhadas na formação de repertórios, que são, no caso específico da transferência, os agentes da transferência. $\mathrm{O}$ trabalho destes agentes pode introduzir na rede de disposições culturais certas inclinações em direção aos repertórios dos quais se ocupam. Em outras palavras, os novos repertórios não estão restritos, em tais casos, aos itens importados como bens - ou não necessariamente a eles apenas -, mas o que atua na cultura são as pessoas, os próprios agentes que estão envolvidos no negócio. Por exemplo, as pessoas podem não ter lido poemas de poetas que introduziram novos itens de um repertório estrangeiro (seja via tradução ou via adoção direta), mas podem "aceitar" tais produtos, por assim dizer, ao reconhecerem as pessoas envolvidas como fontes de instrução, de liderança ou de aconselhamento para determinadas ações.

São muitos os casos de formadores de novos repertórios em que a personalidade deles, a narrativa propagada sobre eles, frequentemente obscurece os produtos concretos por eles propostos. Em outras palavras, os bens, os itens do repertório passam a ser identificados com eles. Por exemplo, estados de espírito e incentivo à defesa da "liberdade", do "heroísmo", do "patriotismo", da "igualdade", ou de atos menos exaltados como "limpeza", "ordem" ou "comida saudável" não são derivados de "escritos", mas daquilo que se ouviu sobre os "escritores ativistas" que muitas vezes entram na categoria de mito.

É possível ampliar e generalizar um pouco esta discussão de forma a sugerir que a formação dos repertórios via transferência deva ser avaliada não apenas pela observação das coisas registradas (direta ou indiretamente), mas também pela tentativa de entender o volume de atividade que a transferência pode ter estimulado. Por exemplo, se há muitos produtores textuais em algum momento, e o negócio da tradução é central para eles, então esta preocupação per se pode criar determinadas inclinações para a adoção de outros repertórios.

Este princípio geral funcionará em muitos outros níveis, que podem ir desde materiais importados a habilidades e tarefas importadas. Refiro-me a uma imensa variedade de questões, como a organização da economia, o desenho de prédios, a instrução de forças armadas, a preparação de comida, a adoção de um tom "familiar" ou "reservado" na interação, o uso de linguagem "simples" ou "refinada", a utilização de voz mais audível ou menos audível, etc. Em suma, em termos de transferência, o que eventualmente contará para a adoção ou a rejeição é a natureza e o volume da atividade dos agentes.

Resumindo, um estudo adequado da transferência no contexto da formação do repertório não pode limitar-se à comparação de itens transferidos com suas fontes, ou à análise de sua natureza e dos processos de adaptação que eles inserem no sistema alvo. $\mathrm{O}$ que precisa ser estudado é a complexa rede de relações entre o estado do sistema receptor, a natureza da atividade de transferência (por exemplo, se se trata de uma atividade de "fluxo permanente" ou de "comprometimento deliberado") e as relações entre poder e 
mercado, com especial atenção à atividade dos formadores do repertório, que são ao mesmo tempo agentes da transferência.

\title{
The making of culture repertoire and the role of transfer
}

\begin{abstract}
In this paper I suggest a set of hypotheses for handling the relations between the making of repertoire and transfer. It is particularly in the context of the study of translation in its accepted sense that I wish to underline the socio-cultural juncture where transfer plays a role. This role may far exceed the range of events with which students of translation normally are concerned, as it sometimes becomes a major factor for the fate of societies and cultures. However, even at times when its role is minor, it is nonetheless present and for a more encompassing theory of translation a non-dismissible parameter.
\end{abstract}

Keywords: culture repertoire; invention; import; translation; transfer.

\footnotetext{
${ }^{1}$ A primeira versão deste artigo foi apresentada no Congresso Internacional Translations: (Re)shaping of Literature and Culture, ocorrido na Universidade Boğaziçi, em Istambul, nos dias 24 e 25 de outubro de 1996, e posteriormente publicada em Target, 9 (2), 1997, pp. 373-381, e em Translations: (Re)shaping of Literature and Culture, editado por S. Paker, Istambul: Universidade de Bogaziçi, 2002, pp. 166-174. O autor agradece as inestimáveis sugestões de Gideon Toury e de Saliha Parker.

* Unidade de Pesquisa da Cultura, Universidade de Tel Aviv

*** Universidade Federal de Pelotas
}

\section{REFERÊNCIAS}

EVEN-ZOHAR, Itamar. Polysystem Studies (=Poetics Today 11:1). Durham: Duke University Press, 1990.

The Making of Culture Repertoire and the Role of Transfer. In: Papers in Culture Research. Tel Aviv: The Culture Research Lab.: Tel Aviv University, 2010.

FRYKMAN, Jonas, and Orvar Löfgren. Culture Builders: A Historical Anthropology of MiddleClass Life. Trans. Alan Crozier. Foreword by John Gillis. New Brunswick, N.J.: Rutgers University Press, 1987.

LOTMAN, Jurij. On the Semiotic Mechanism of Culture. New Literary History IX: 2, 1978, pp. 211-232.

, and Boris Uspenskij. O Semioticeskom mexanizme kul'tury. In: Trudy po znakovym sistemam V, Tartu, 1971, pp. 144-166.

SEGAL, Dmitri. Aspects of Structuralism in Soviet Philology. Tel Aviv: Porter Institute, 1974. Disponível em: http://www/tau.ac.il/tarbut/pubtexts/segal.

SWIDLER, Ann. Culture in Action: Symbols and Strategies. American Sociological Review, 51 (April), 1986, pp. 237-286. 